\title{
Combined transscleral fixation of an artificial iris prosthesis with an intraocular lens
}

\author{
Combinação de fixação transescleral de prótese de íris artificial com lente intraocular
}

Uzeyir Gunenc ${ }^{1}$, Taylan Ozturk ${ }^{1}$, Gul Arikan ${ }^{1}$, Mahmut Kaya $^{1}$

\begin{abstract}
Post-traumatic aniridia combined with aphakia may be seen after globe injury. Aside from esthetic aspects, partial or total loss of the iris tissue may also be related to various degrees of glare and photophobia. Such patients suffer from severe visual impairment secondary to aphakia. Herein we describe a novel surgical technique for the management of an aphakic eye with traumatic aniridia for a patient who underwent transscleral fixation of a custom-tailored artificial iris prosthesis combined with a rigid intraocular lens $(\mathrm{IOL})$. Tight suturing of the $\mathrm{IOL}$ haptic eyelets on the silicone iris prosthesis and fixation of such a complex to the scleral wall may provide excellent cosmetic and functional outcomes in aphakic eyes with aniridia.
\end{abstract}

Keywords: Aniridia; Aphakia; Postcataract; Cataract extraction; Iris/injuries; Eye injuries; Lens implantation, Intraocular; Prosthesis design

\section{RESUMO}

Aniridia pós-traumática combinada com afacia pode ser observada após lesões do globo ocular. Além do ponto de vista estético, a perda parcial ou total do tecido da íris também pode estar relacionada com vários graus de ofuscamento e fotofobia. Estes pacientes sofrem de deficiência visual grave secundária a afacia. Relata-se uma técnica cirúrgica inovadora para tratamento de um olho com afacia associada à aniridia traumática que foi submetido à fixação transescleral de uma prótese de íris artificial feita sob medida combinada com uma lente intraocular rígida (IOL). A sutura das alças da IOL sobre a prótese iriana de silicone, e a fixação desse complexo na parede escleral podem proporcionar excelente resultado estético e funcional em olhos afácicos com aniridia.

Descritores: Aniridia; Afacia pós-catarata; Extração de catarata; Iris/lesões; Traumatismos oculares; Implante de lentes intraocular; Desenho de prótese

\section{INTRODUCTION}

Post-traumatic iris defects combined with crystalline lens abnormalities are among the major complications of globe injuries. Pupillary defects may cause glare and photophobia to various degrees; however, traumatic aniridia may lead to severe visual deterioration. Because corneal endothelial cell density is reduced in eyes with a traumatic cataract, every surgical trauma entails a potential risk of aggravating corneal decompensation ${ }^{(1-3)}$. After custom-tailored iris prosthesis became available for ocular implantation, some authors have described a combined surgical approach for treating aphakia and aniridia with haptic fixation of an intraocular lens (IOL) on artificial iris implants prior to intraocular placement ${ }^{(4,5)}$. Herein we describe a new surgical technique for simultaneously treating aniridia and aphakia. A sclerally sutured rigid IOL was first fixated on a custom-tailored artificial iris prosthesis by both of its haptics, after which intraocular implantation was performed by suturing IOL to the scleral wall.

\section{CASE REPORT}

A 56-year-old otherwise healthy female had experienced total iris emanation and crystalline lens luxation secondary to a blunt trauma to her left eye. She had previously undergone lensectomy and pars plana vitrectomy at another center. A complete ophthalmologic examination revealed a clear cornea with a normal fundus and a visual acuity of 20/20 with +12.0 diopters correction in the affected eye. The combined transscleral fixation of a single-piece polymethylmetha- crylate (PMMA) IOL (CZ70BD; Alcon Laboratories, Fort Worth, TX, USA) with the implantation of a custom-tailored artificial iris prosthesis (Dr. Schmidt Intraocularlinsen GmbH, HumanOptics AG, Erlangen, Germany) was scheduled for simultaneously treating aniridia and aphakia. In order to match the color of the healthy iris, a custom-tailored artificial iris prosthesis was produced.

Under topical anesthesia, two conjunctival peritomies were made at the 3 and 9 o'clock meridians before performing a superior $7.0-\mathrm{mm}$ clear corneal incision. Subsequently, an ophthalmic viscosurgical device (OVD) was injected to protect the corneal endothelium. After hitching the 9-0 polypropylene looped-sutures with a long-curved needle (PC-9; Alcon Surgical, Fort Worth, TX, USA) to the haptic eyelets of PMMA IOL, both pairs of such needles passed through the periphery of the artificial iris prosthesis (Figure $1 \mathrm{~A}$ ). The haptics were tightly attached to the back of the iris implant. Next, IOL and artificial iris complex were ab-internally fixed to the scleral wall at the 3 and 9 o'clock meridians, approximately $1 \mathrm{~mm}$ posterior to the limbus. After passing the needles through the marked scleral points, $\mathrm{IOL}$ and the artificial iris complex were implanted. The complex was retracted to be stabilized and well-centered after the withdrawal of both needles through the pars plana. Polypropylene sutures were tied to the sclera, and the suture knots were buried into the sclera at both sides. To ensure placement within the sclera, the suture end and knot were buried into the created scleral tunnel using a PC-9 needle after knotting the suture onto itself. The artificial iris did not interfere with this process because there was no knot between the
Submitted for publication: December 9, 2014

Accepted publication: March 18, 2015

Department of Ophthalmology, Dokuz Eylul University School of Medicine, Izmir, Turkey.
Funding: No specific financial support was available for this study.

Disclosure of potential conflicts of interest: None of the authors have any potential conflict of interest to disclose.

Corresponding author: Taylan Ozturk. Albatros-9, 152, Daire: 26 - Mavisehir, Karsiyaka - 35540, Izmir - Turkey -E-mail: ataylan6@yahoo.com 
artificial iris and ciliary body. The corneal incision was sutured with a 10-0 non-absorbable nylon suture, and OVD was gently removed from the anterior chamber. The conjunctiva was subsequently closed with 80 polyglactin 910 (Vicry| ${ }^{\circledR}$, Ethicon Inc) sutures (Figure 1 B). The patient was satisfied with the cosmetic appearance from the early postoperative period (Figure 2). Over the first postoperative week, the patient had no complaints of any persisting glare and photophobia, and visual acuity was found to be $20 / 20$ with -0.50 diopters of astigmatism in her left eye.

\section{DISCUSSION}

Iris defects combined with aphakia are serious problems frequently encountered after globe injuries. Aside from esthetic aspects, partial or total loss of iris tissue may also be related to various degrees of glare, photophobia, and visual impairment. In patients with major iris defects, an artificial iris prosthesis provides satisfactory anterior segment reconstruction with a remarkable functional outcome $e^{(3-10)}$.

Various implants have been developed for the treatment of aphakia with aniridia. Some authors reported on effective and safe surgical intervention with Morcher black-diaphragm IOL (Morcher 67F BDI, Morcher GmBH, Stuttgart, Germany) for the treatment of both total or partial aniridia in aphakic cases ${ }^{(6,7)}$. The Ophtec iris reconstruction lens with the color options of brown, blue, and green (Ophtec USA, Boca Raton, FL, USA) has also been reported to provide better cosmetic outcomes as well as remarkable visual improvement ${ }^{(8,9)}$. In cases with partial iris defects, intraocular implantation of the Artisan iris reconstruction implant (Ophtec, Groningen, The Netherlands) may be chosen for cosmetic and functional improvement. Such a device can be attached to the remaining iris tissue at its periphery; however, an optical lens system enabling various dioptric powers is placed in its center ${ }^{(10)}$. A custom-tailored artificial iris prosthesis provides a much
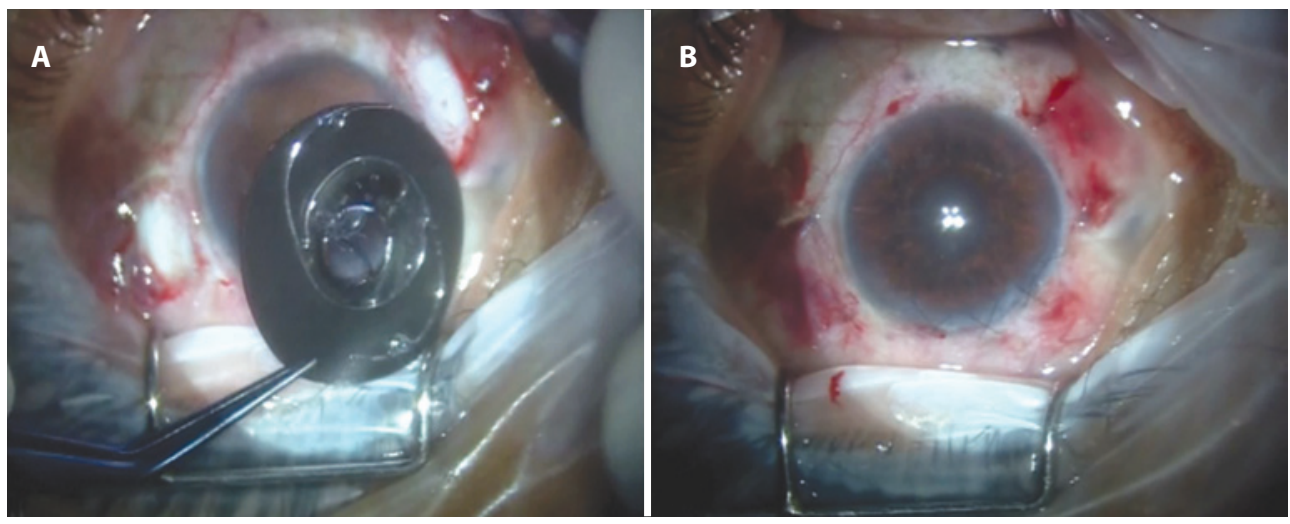

Figure 1. (A) Haptics of a single-piece polymethylmethacrylate (PMMA) intraocular lens (IOL) were tightly attached to the back of the iris implant using 9-0 polypropylene looped-sutures with a long-curved needle (PC-9; Alcon Surgical). (B) Operated eye at the end of the surgery.
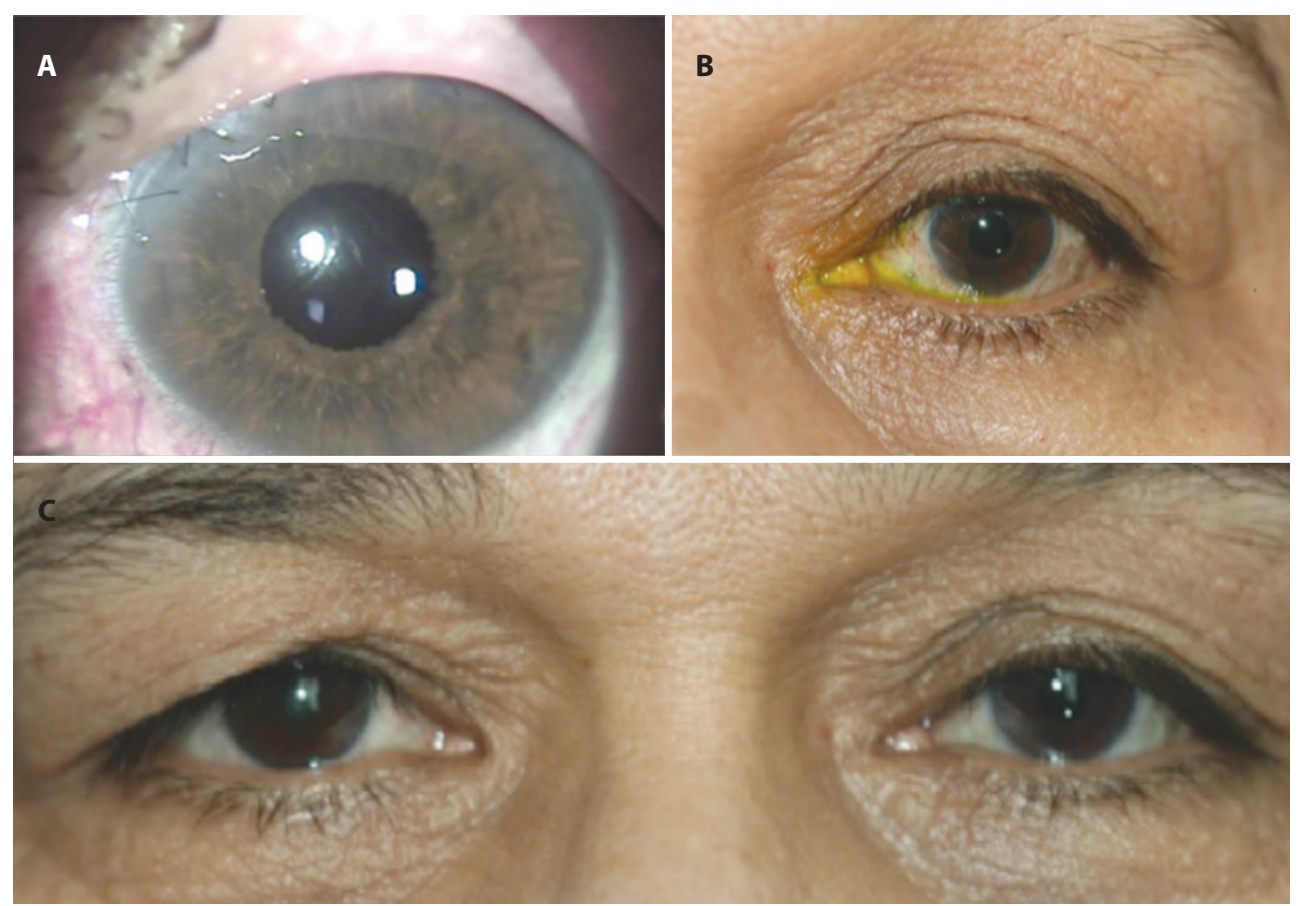

Figure 2. Operated eye at postoperative day one (A) and after first week (B). Acceptable cosmetic appearance of the left eye (C). 
better cosmetic outcome because it is produced according to the exact iris color of the fellow eye. Because the management of aphakia is not possible with such artificial iris implants, the transscleral fixation of IOL has to be scheduled in aphakic eyes with a lack of a sufficient capsular support. Hence, many authors have published an excellent visual prognosis with transsclerally fixated IOLs in aphakic cases without any capsular support ${ }^{(2-5)}$. In order to reduce the risk of both corneal decompensation and macular edema, transscleral fixation of a standard IOL in combination with a custom-tailored artificial iris prosthesis in the same surgical session has been published very recently in cases with concomitant aniridia and aphakia ${ }^{(4,5)}$. Forlini et al. fixed a monopiece foldable IOL centrally on the back side of the artificial iris prosthesis ${ }^{(4)}$, and Spitzer et al. reported on the implantation of such a custom-tailored prosthesis combined with a three-piece foldable IOL through a superior corneoscleral tunnel with a length of $5 \mathrm{~mm}^{(5)}$. However, we used PMMA IOL that was tightly sutured onto the back side of the artificial iris prosthesis with 9-0 polypropylene looped-sutures in its haptic eyelets in order to provide the best fixation. Although a major disadvantage of such a procedure was the necessity of extended corneal incision, a visual acuity of 20/20 with -0.50 diopters of astigmatic correction in the affected eye was achieved only one week after the operation.

Herein we presented a novel surgical technique for managing an aphakic case with traumatic aniridia undergoing transscleral fixation of a Dr. Schmidt custom-tailored artificial iris prosthesis combined with PMMA IOL. Suturation of the IOL haptics on the artificial iris prosthesis and the transscleral fixation of this complex to the scleral wall provide a good cosmetic and functional outcome in aphakic cases with aniridia.

\section{REFERENCES}

1. Yeniad B, Corum I, Ozgun C. The effects of blunt trauma and cataract surgery on corneal endothelial cell density. Middle East Afr J Ophthalmol. 2010;17(4):354-8. Comment in: Middle East Afr J Ophthalmol. 2012;19(2):269-70; author reply 270.

2. Lockington D, Ali NQ, Al-Taie R, Patel DV, McGhee CN. Outcomes of scleral-sutured conventional and aniridia intraocular lens implantation performed in a university hospital setting. J Cataract Refract Surg. 2014:40(4):609-17.

3. Hanumanthu S, Webb LA. Management of traumatic aniridia and aphakia with an iris reconstruction implant. J Cataract Refract Surg. 2003;29(6):1236-8.

4. Forlini C, Forlini M, Rejdak R, Prokopiuk A, Levkina O, Bratu A, et al. Simultaneous correction of post-traumatic aphakia and aniridia with the use of artificial iris and IOL implantation. Graefes Arch Clin Exp Ophthalmol. 2013:251(3):667-75. Comment in: Graefes Arch Clin Exp Ophthalmol. 2013;251(10):2493-4. Graefes Arch Clin Exp Ophthalmol. 2013;251(10):2491.

5. Spitzer MS, Yoeruek E, Leitritz MA, Szurman P, Bartz-Schmidt KU. A new technique for treating posttraumatic aniridia with aphakia: first results of haptic fixation of a foldable intraocular lens on a foldable and custom-tailored iris prosthesis. Am J Ophthalmol. 2012;130(6):771-5.

6. Aslam SA, Wong SC, Ficker LA, MacLaren RE. Implantation of the black diaphragm intraocular lens in congenital and traumatic aniridia. Ophthalmology. 2008;115(10): 1705-12.

7. Beltrame G, Salvetat ML, Chizzolini M, Driussi GB, Bussato P, Di Giorgio G, et al. Implantation of a black diaphragm intraocular lens in ten cases of post-traumatic aniridia. Eur J Ophthalmol. 2003;13(1):62-8.

8. Price MO, Price FW Jr, Chang DF, Kelley K, Olson MD, Miller KM. Ophtec iris reconstruction lens United States clinical trial phase I. Ophthalmology. 2004;111(10):1847-52.

9. Mashor RS, Bahar I, Kaiserman I, Berg AL, Slomovic A, Rootman DS. Combined penetrating keratoplasty and implantation of iris prosthesis intraocular lenses after ocular trauma. J Cataract Refract Surg. 2011;37(3):582-7.

10. Smina ML, Odenthal MT, Gortzak-Moorstein N, Wenniger-Prick L, Völker-Dieben HJ. Implantation of the Artisan iris reconstruction intraocular lens in 5 children with aphakia and partial aniridia caused by perforating ocular trauma. J AAPOS. 2008;12(3):268-72. 